Abstracta Iranica Abstracta Iranica

Revue bibliographique pour le domaine irano-aryen

Volume 23 | 2002

Comptes rendus des publications de $\mathbf{2 0 0 0}$

\title{
«L'image de la femme dans la littérature moderne persane ». Luqmān, XVII, 1, (2000), pp. 55-66.
}

\section{Christophe Balaÿ}

\section{(2) OpenEdition}

1 Journals

Édition électronique

URL : http://journals.openedition.org/abstractairanica/35867

DOI : 10.4000/abstractairanica.35867

ISSN : 1961-960X

\section{Éditeur :}

CNRS (UMR 7528 Mondes iraniens et indiens), Éditions de l'IFRI

\section{Édition imprimée}

Date de publication : 15 mai 2002

ISSN : 0240-8910

\section{Référence électronique}

Christophe Balaÿ, « «L'image de la femme dans la littérature moderne persane ». Luqmān, XVII, 1, (2000), pp. 55-66. », Abstracta Iranica [En ligne], Volume 23 | 2002, document 307, mis en ligne le 08 février 2010, consulté le 25 septembre 2020. URL : http://journals.openedition.org/abstractairanica/ 35867 ; DOI : https://doi.org/10.4000/abstractairanica.35867

Ce document a été généré automatiquement le 25 septembre 2020.

Tous droits réservés 


\title{
«L'image de la femme dans la littérature moderne persane ». Luqmān, XVII, 1, (2000), pp. 55-66.
}

\author{
Christophe Balaÿ
}

1 Intéressant article d'une dizaine de pages qui met en perspective six textes de prose persane moderne (Zībā de Ḥejāzī ; Ses yeux de 'Alavī ; Une femme de trop de Âl-e Aḥmad ; Le mari d'Āhū Huānūm d'Afğānī; Sūvašūn de Dānešvar et La Disparition de Solūč de Dowlatābādī). L'A. analyse brièvement mais avec précision comment l'image de la femme dans la prose persane moderne évolue au fur et à mesure que change la société. C'est cet aller et retour entre la réalité sociale et la littérature qui la reflète et l'anticipe parfois, qui constitue le trait le plus caractéristique de cette évolution. Toutefois, l'A. devrait au moins expliquer pourquoi elle écarte le plus magique et le plus fort de tous ces textes, La chouette aveugle, où l'image de la femme prend des couleurs plus sombres et inquiétantes, sans compter d'autres femmes non moins intéressantes comme Ābjī Hुānom, 'Alaviye Hānom, Kātrīn et toutes ces femmes qui peuplent les récits de Ș. Hedāyat.

\section{INDEX}

Thèmes : 11.1.2. Littérature persane moderne 
AUTEURS

CHRISTOPHE BALAŸ

IFRI - Téhéran 